\title{
THE DIGITALIZATION OF BRAZILIAN CITIES: A STUDY BASED ON INFORMATION FROM THE MINISTRY OF COMMUNICATIONS
}

\section{DIGITALIZAÇÃO DAS CIDADES BRASILEIRAS: UM ESTUDO INFORMACIONAL BASEADO NO MINISTÉRIO DAS COMUNICAÇÕES}

\begin{abstract}
ALEX VOLNEI TEIXEIRA
Professor at the First Nations University of Canada, Season Lecture at the University of Regina, Saskatchewan, Canada. Ph.D. in Urban Management - Strategic Digital City at Catholic University of Parana (PUCPR), Master of Science in Information Technology at the Federal University of Parana (UFPR). Major Degree in Business Management at the University of Maringá. Bachelor Degree in Marketing University of Southern Santa Catarina. Books: Logistics in Public Administration: Concepts and methods (2014); Management; Law and Technology Citizenship Service (2014); Management, Design and New Technologies (2014); Society, Law, and Sustainability (2013). Researcher CNPq - Research Group Cooperation and Relations Contractual Development and sustainability of the Americas. Work and research in the areas of development and Virtual Environments Innovation Enterprise, with emphasis on Strategic Management, Information Technology, Information Systems, Urban Management, Smart Cities, Digital Cities and Digital Strategic City.
\end{abstract}

\section{SERGIO SILVA RIBEIRO}

Researcher in Digital City, Smart City, Strategic Digital City, Public Management (New Public Management), Organizational Intelligence, Strategic Management, Knowledge Management, Evidence-based, Digital Image Processing, Machine Learning, and Data Mining. Email: sergio.silva.ribeiro@uregina.ca. 


\section{VALDOMIRO MENDES ARANTES}

Mestre em Letras pela Universidade Federal do Paraná - UFPR (1990). Atualmente é professor - Colégio da Polícia Militar - Cel. PM Felippe de Sousa Miranda. Email: professorvaldomiro@hotmail.com

\section{ABSTRACT}

Throughout the history of humankind, many cities have arisen and built from different needs and purposes. Mainly after the industrial revolution, many cities appear as the result of a process of urbanization, generating a new social context considered by some as the information society, imposing on the state new way of articulating public policies with society. Moreover, with the advent of Information and Communication Technologies (ICT) new concepts associated with the city like cyberspace, cybercity, virtual city, electronic city and Digital City arise. The purpose of this work was to discuss the concept of Digital City, from the search for a theoretical reference since the 1980s, understanding the characteristics of projects implemented since then around the world. From this understanding, bring a discussion to the Brazilian context of the Digital City project promoted by the Ministry of Communications (MC) as a public policy of insertion of the population in some Brazilian municipalities in the information age. Methodologically the research moves into its qualitative character of a specific nature, supported by the authorial coupling. As a result, the paper reiterates concepts and questions about the goa

KEYWORDS: Cities; Information; Public Policies; Information Access.

\section{RESUMO}

Ao longo da história da humanidade, muitas cidades surgiram e foram construídas a partir de diferentes necessidades e propósitos. Principalmente após a revolução industrial, muitas cidades surgem como resultado de um processo de urbanização, gerando um novo contexto social considerado por alguns como a sociedade da informação, impondo ao Estado uma nova maneira de articular políticas públicas com 
a sociedade. Além disso, com o advento das Tecnologias de Informação e Comunicação (TIC) surgem novos conceitos associados à cidade como o ciberespaço, a cibercidade, a cidade virtual, a cidade eletrônica e a cidade digital. $\mathrm{O}$ objetivo deste trabalho foi discutir o acesso à informação e o conceito de Cidade Digital, a partir da busca por um referencial teórico desde a década de 1980, compreendendo as características dos projetos implantados desde então. A partir desse entendimento, trazer uma discussão para o contexto brasileiro do projeto Cidade Digital promovido pelo Ministério das Comunicações (MC) como a política pública de inserção da população em alguns municípios brasileiros na era da informação. Metodologicamente a pesquisa se traduz em seu caráter qualitative de natureza especifica, sustentado pelo acoplamento autoral e infométrico. Como resultado reitera conceitos e apronfunda endenimento científico acerca do objetivo elencado.

PALAVRAS-CHAVE: Cidades, informação, políticas públicas, tecnologia da informação.

\section{INTRODUCTION}

Defining a City is not a simple task because its discussion involves several concepts: it is something real and representational, in space and time, lived and (re) constructed socially, by capitalism and social struggles; social space where everyone has the right to come and go, share goods and services, produce and discuss their development and use; poetry. In this way, due to its different concepts, it can be confused with the concept of Urban, although they are distinct ones, where the city can be seen as the concrete and the urban the abstract. However, despite the different concepts, some points are common, that is: the City is a material space of social relations; it can not be confused with urban; it is the place where citizenship makes sense; it is a mixture of representations; it can be a place of reference; it is one of the stages of politics; and in the City, as well as in the countryside, the daily dilemmas are present. 
Throughout the history of humankind, many cities have arisen and built from different needs and purposes. Especially after the industrial revolution, many cities arise as a result of a process of urbanization, generating a new social context considered by some as the information society, imposing on the state new forms of articulation of public policies with society (CASTELLS, 2002; LIMA, 2002). In addition, with the advent of Information and Communication Technologies (ICT) new concepts associated with the city like cyberspace, cybercity, virtual city, electronic city and Digital City arise. In the same way, as with the concept of city, the concept of Digital City is diversified, and there is no uniformity with respect to its nomenclature among its various authors.

Brazil is made up of 5,565 municipalities, with significant differences between them, where a large part of these (3,921 municipalities) are represented by small cities with less than 20,000 inhabitants (DEMOGRÁFICO, 2010). Moreover, in this universe of small cities there are cases like that of União da Serra, a city in Rio Grande do Sul, with only 18 inhabitants. Due to the reality and limitations of these small municipalities, the incorporation of new ICTs become a major challenge (ANGELIN \& DE MEZA, 2016).

The purpose of this work was to discuss the concept of Digital City, from the search for a theoretical reference since the 1980s, understanding the characteristics of projects implemented since then around the world. From this understanding, bringing a discussion to the Brazilian context of the Digital City project promoted by the Ministry of Communications (MC) as a public policy of insertion of the population in some Brazilian municipalities in the information age.

\section{DIGITAL CITY}

The term Digital City arises around 1980 and Alvin Toffler discusses it indirectly, when discussing the evolutionary stage of interactivity of social life made possible by the development and use of technological information systems in the context of the cities. Subsequently, in 1985, the American company America Online, registers the term Digital City and creates the Digital City website that presents the 
American cities in a kind of electronic catalog. The concept expands to encompass the idea of a platform for fostering community networks, integrating real-time urban information and creating public spaces for citizens. It is from this new conception that more than 100 European organizations have come together since 1994 to discuss topics related to telematic applications and technologies for the integration of cities with their citizens.

Currently there are different views regarding the concept of what a digital city would be. For Levy (2010), it would represent a social process of collective intelligence interactively integrated into a network in cyberspace. It can also be understood as the stage of development of a community, in relation to its capacity to use ICTs for the integration of social life, as well as a social platform or an intercommunity network between the global and the local (GUERREIRO, 2006). Lemos (2007) has a similar definition, however, with the concept of cyborg as the city of cyberculture, composed of telematic networks, transportation, energy, sanitation, lighting and communication, according to him an artifice, an imaginary and concrete machine .

The different definitions of digital city, in general, can be grouped into four types of experience: the web representation of a certain site in the form of a portal; creation of infrastructure, services and public access in urban areas for the use of new technologies and telematic networks; 3D modeling of urban spaces by means of Spatial Information Systems (such as Spacial Information System - SIS and Geographic Information System - GIS); and electronic metaphorical representations in the form of virtual communities such as forums, chats, news, etc.(Table 1). Some digital city projects may be public, private, or a public-private partnership in general with the involvement of civil society (LEMOS, 2006; TEIXEIRA; DUARTE; LAURINDO, 2014). 
Table 1 - Digital Cities Projects

\begin{tabular}{|c|c|c|}
\hline $\begin{array}{c}\text { Yea } \\
\mathbf{r}\end{array}$ & City /Country & Features \\
\hline $\begin{array}{c}198 \\
5\end{array}$ & AOL / USA & $\begin{array}{l}\text { Private organization. Information on American cities on a website. Online } \\
\text { consultation and chat services. }\end{array}$ \\
\hline $\begin{array}{c}199 \\
4\end{array}$ & $\begin{array}{l}\text { Amsterdam / } \\
\text { Netherlands }\end{array}$ & $\begin{array}{l}\text { Digital Design Stad (DDS) involving public power and private } \\
\text { initiative. Representation of the city through telematic networks, creation } \\
\text { of infovia for integration of citizens with the public power. }\end{array}$ \\
\hline $\begin{array}{c}199 \\
4\end{array}$ & Bologna / Italy & $\begin{array}{l}\text { Project Bologna Digital, initiative of the State authority. Website that offers } \\
\text { users a representation of physical spaces, such as squares, streets, } \\
\text { shopping centers, hotels, libraries, cultural centers, and others by means of } \\
\text { a digital mockup. }\end{array}$ \\
\hline $\begin{array}{c}199 \\
6\end{array}$ & Helsinki / Finland & $\begin{array}{l}\text { Helsinki Digital Project, State authority and private initiative. Virtual } \\
\text { community providing online services to companies and residents, with } \\
\text { implementation of ICT infrastructure. Implementation of the concept of e- } \\
\text { democracy (a way of discussing debates between government and the } \\
\text { population through the internet). }\end{array}$ \\
\hline $\begin{array}{c}199 \\
8\end{array}$ & Kyoto / Japan & $\begin{array}{l}\text { Kyoto Digital Project, a Kyoto University initiative with civil society, public and } \\
\text { private. Creation of social infrastructure of information destined to the daily } \\
\text { use of the citizens like purchases, businesses, transport, education, social } \\
\text { security among others. Virtual interaction using 2D and 3D technology. }\end{array}$ \\
\hline $\begin{array}{c}199 \\
8\end{array}$ & Toronto / Canada & $\begin{array}{l}\text { Project Netville, consortium between public and private companies. Creation } \\
\text { of a high-speed local network, connecting } 64 \text { homes and offering internet } \\
\text { access services, videophone, online record player, online health services, } \\
\text { discussion groups, and educational and entertainment applications. }\end{array}$ \\
\hline $\begin{array}{c}199 \\
8\end{array}$ & $\begin{array}{c}\text { Bavaria } \\
\text { and Meissen / } \\
\text { Germany, Horsen / } \\
\text { Denmark,Canavese } \\
\text { / Italy, Hampshire / } \\
\text { England, Valencia / } \\
\text { Spain and } \\
\text { Vara / Switzerland }\end{array}$ & $\begin{array}{l}\text { Infoville project involving seven cities in the European Union. Virtual } \\
\text { community in a standardized platform, offers telematic services on municipal } \\
\text { and regional information, education, transport, e-commerce, among others. }\end{array}$ \\
\hline $\begin{array}{c}199 \\
9\end{array}$ & $\begin{array}{l}\text { Aveiro } \\
\text { Portugal }\end{array}$ & $\begin{array}{l}\text { Aveiro Digital Project, an initiative of a consortium involving the City Council, } \\
\text { the University of Aveiro and CET / Portugal Telecom. With civil society } \\
\text { participation, it involves public kiosks, access to schools and libraries, as well } \\
\text { as other public services. }\end{array}$ \\
\hline $\begin{array}{c}200 \\
0\end{array}$ & $\begin{array}{l}\text { Edinburgh/ } \\
\text { Scotland }\end{array}$ & $\begin{array}{l}\text { Living Memory Project, a public-private initiative. Providing information about } \\
\text { the city such as health, rental of things in general, lost and found, among } \\
\text { others, through telematic devices }\end{array}$ \\
\hline $\begin{array}{c}200 \\
1\end{array}$ & $\begin{array}{c}\text { Small Municipalities } \\
\text { / Brazil }\end{array}$ & $\begin{array}{l}\text { Digital Cities Project, a public federal initiative. Improve the ICT infrastructure } \\
\text { of the cities with less than } 50 \text { thousand inhabitants, providing access to } \\
\text { the internet, computerization of public services and integration platform } \\
\text { between citizen and local public power. }\end{array}$ \\
\hline
\end{tabular}

Source: Prepared by the authors based on Ishida \& Isbister (200), Wellman et al (2001), Guerreiro (2006), and Leite (2006)

In Table 1, some examples of Digital Cities projects developed around the world are presented in temporal order. These are projects that started in the 1980s, covering different regions of the world and combine diverse and common characteristics. 


\subsection{STRATEGIC DIGITAL CITY}

The term Strategic Digital City (SDC) emerges in Rezende (2012) as a broader concept for digital city, which goes beyond the implementation of ICTs through hardware and software infrastructures, it is a broader concept that approaches strategy planning and information in the context of the digital city. A city that has defined strategies, within the themes of the city as health, education, transportation, tourism, among others, and uses the ICT to integrate the citizen to the City (Figure 1), can be considered, in part, a Digital Strategic City (REZENDE , 2016).

Figure 1 - Relationships that make up a Strategic Digital City

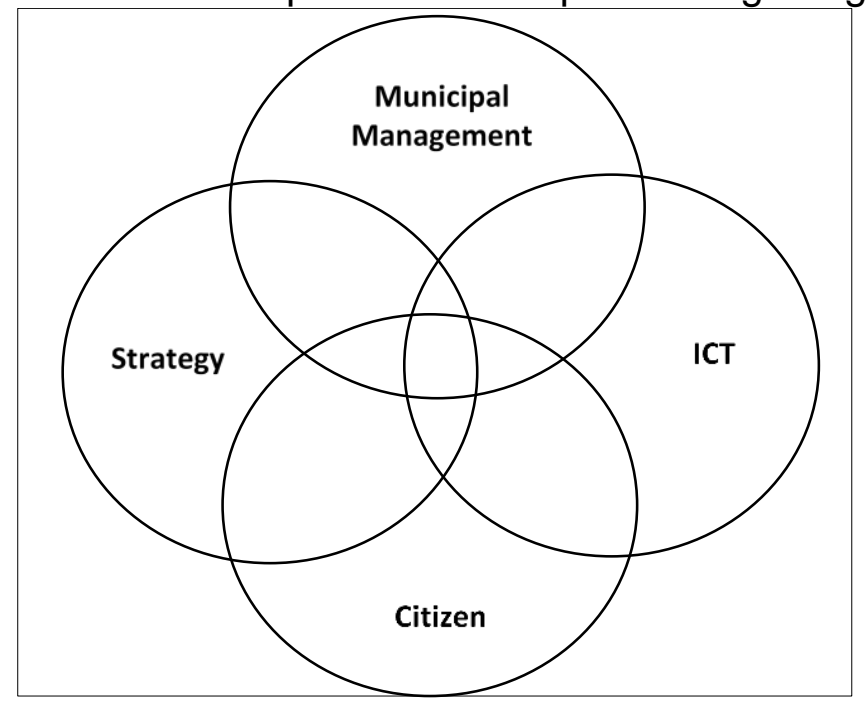

Source: Prepared by the authors

Rezende $(2012,2018)$ creates a new concept of strategic planning for the digital city at a time when researches related to digital city and smart city are expanding. In its work, this is presented in the context of the Brazilian reality, according to the guidelines of the legislation for the elaboration and execution of the Municipal Master Plan, Pluriannual Plan, Participative Master Plan, Budgetary Guidelines Law, among others. Therefore, Strategic Digital City involves the application of ICT resources in the management of the municipality and in the provision of information and services to citizens. 
Figure 2 - Digital City Strategy Model

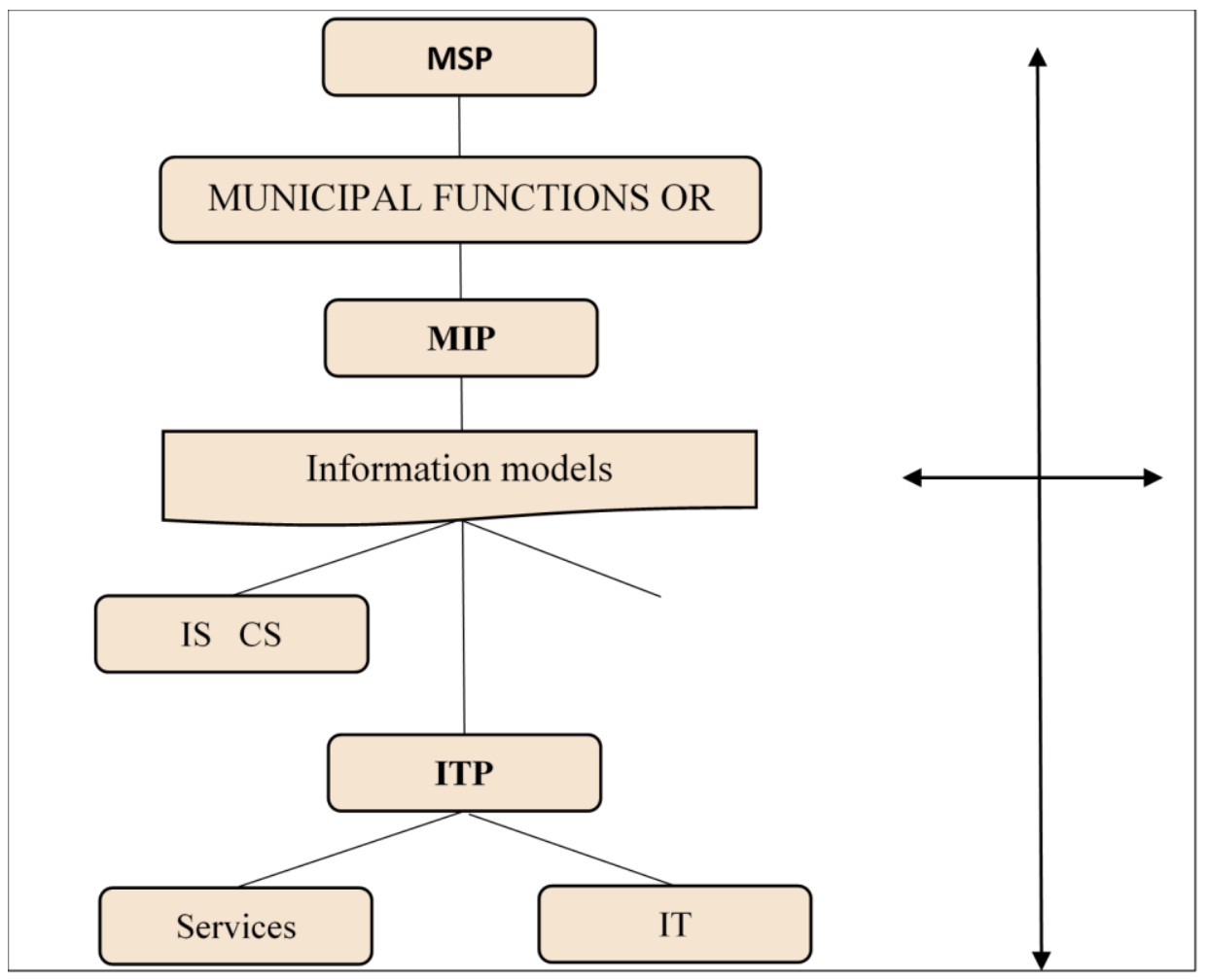

Source: Rezende $(2012,2018)$

As it can be seen in the Digital City Strategy (DCS) model, presented in Figure 2 , its implementation requires the elaboration of the projects: municipal strategic planning (MSP) with the municipality's objectives and strategies through municipal functions or themes; municipal information planning (MIP); and planning of information technology (ITP) of the municipality, city hall and municipal public organizations involved. Information models of the municipal functions or themes are the main MIP project products that are prerequisites for the planning of municipal information systems (IS) and knowledge systems (KS) and their necessary human resources (HR), whether they are local managers, municipal officials or citizens. The ITP project will allow the planning of the information technology (IT) resources and respective municipal services offered by the municipality to the citizens (REZENDE, 2012, 2018). 


\section{RESEARCH METHODOLOGY}

The search for an understanding about the theme was what guided this work. Vergara (2005) mentions that a research qualifies for its purposes and means. As for the ends, it can be of the exploratory type, investigating through empirical and theoretical research the problems presented in relation to its theme and descriptive because it seeks to describe characteristics, perceptions and expectations of the analyzed theme.

According to Gil (2002), the exploratory research "aims to provide greater familiarity with the problem, in order to make it more explicit or to construct hypotheses". According to the author, "the descriptive research has as main objective the description of the characteristics of a certain population or phenomenon or, therefore, the establishment of relations among variables". In addition, to understand "how" or "why" of a particular phenomenon, one can resort to the case study method, which YIN (1989) states "it is an empirical inquiry that investigates a contemporary phenomenon within a real-life context, when the boundary between the phenomenon and the context is not clearly evident and where multiple sources of evidence are used.

This work started with a bibliographical research for the theoretical foundation related to the research theme, with the aim of conceptualizing "Digital City", "Smart City", "Digital City Strategic", as well as the understanding of the Ministry of Communications in proposing the project "Digital Cities ".

The object of our case study was the Digital Cities Project of the MC. Moreover, for its study were made data referenced by the Ministry of Communications on the ministry's own website at "http://www.mcti.gov.br/". It was also collected data available in the PORTAL BRASILEIRO DE DADOS ABERTOS, by the electronic address "http://dados.gov.br/dataset/cidades-digitais". Among the cities covered by the project, for this work, the Municipality of Não-Me-Toque was selected for study and analysis with the purpose of understanding the scope of implementation of this project after its completion. 


\section{RESULTS AND DISCUSSION}

Digital City Projects in Brazil have been carried out in recent years as a public policy program. The Brazilian federal government, through the Ministry of Communications (MC), instituted the Digital Cities program through Decree no. 376, of August 19,2001 . One of the purposes of the program, administered by the Digital Inclusion Secretariat (DIS), is to promote digital inclusion and expansion of egovernment services in municipalities (CASTRO, 2015).

The project aims at a continuous and sustainable policy in the long term, integrating actions of digital inclusion (Figure 3). The main objectives of the project are: improving quality and transparency in public management; the democratization of access; the promotion of a creative and sustainable economy; the creation and development of content; the construction of open network collaboration environments. It is a structuring project that aims to establish a digital culture in the Brazilian society (BRAZIL, 2014).

Figure 3 - Digital City Model of the MC

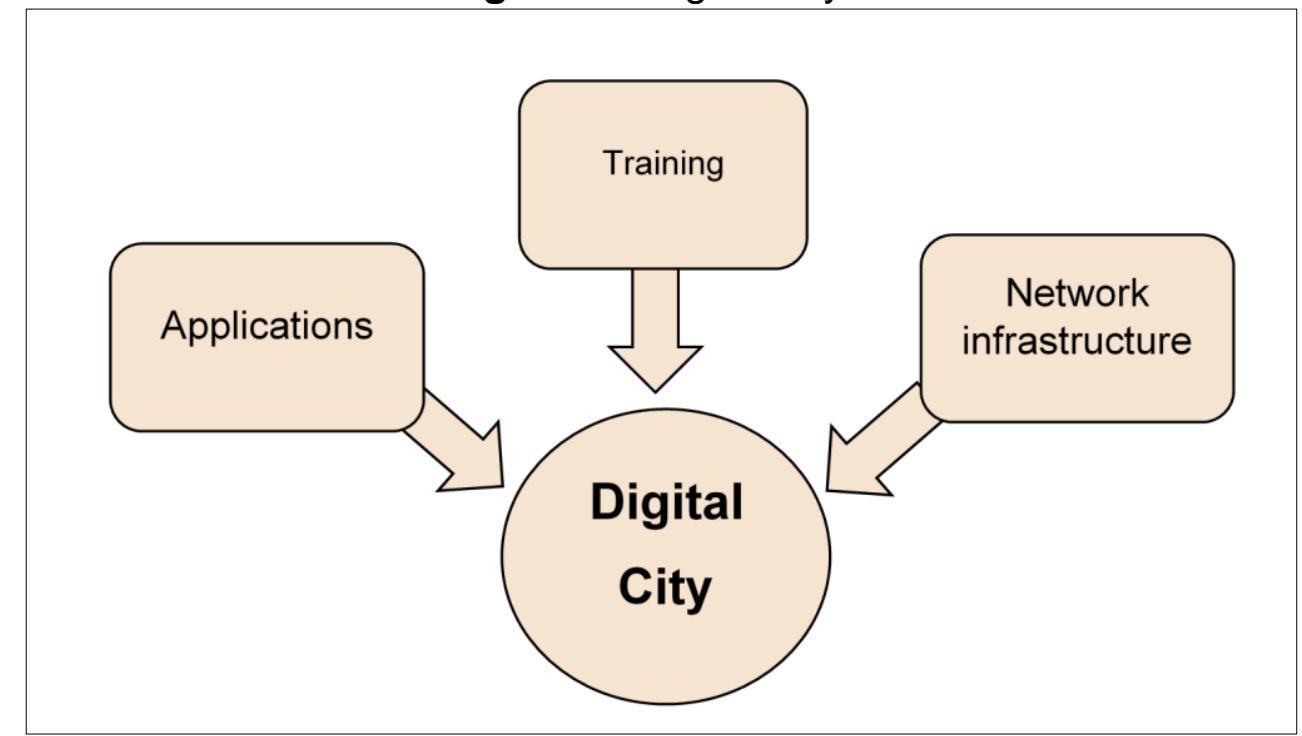

Source: Brazil (2014)

According to the phases related to the program from the point of view of responsibility, they are shared between the $M C$ and the municipality. Therefore, it is up to MC: hiring the integrating company, offering training for public servants; deploy 
e-government applications with an operating guarantee for one year; provide the visual identity standard, provide tracking and monitoring tools; deployment of fiber optic infrastructure; guarantee equipment for 3 years and finally donate the infrastructure to the municipality. In relation to the municipality is its responsibility: to appoint a representative to dialogue with the $M C$, companies and other institutional partners; ensuring spaces and facilitating the means for infrastructure deployment; obtain the necessary licenses for network deployment; hire internet connection link; designate public servants for training, ensuring their participation in them; ensure the functioning of e-government applications after one year; apply the visual identity standard provided by $\mathrm{MC}$; and keep the information up-to-date on the monitoring and follow-up tools provided by MC (ANGELIN \& DE MEZA, 2016).

The MC opened two public calls so that the municipalities could send projects of interest. The first call was in 2012 through Notice 001/2012-MC and the second call through the Opening Ordinance on February 13, 2013 (Graphs 2 and 3). Both prioritizing municipalities with number of inhabitants, according to IBGE, less than 50 thousand. In the 2012 call it was mentioned that the municipalities of the north and northeast region of Brazil would have priority, and in the call of 2013 the municipalities distant within fifty kilometers of the backbone of Telebrás (MC, 2015).

Graph 1 - Municipalities selected by the MC in (a) 2012 and (b) 2013 grouped by region

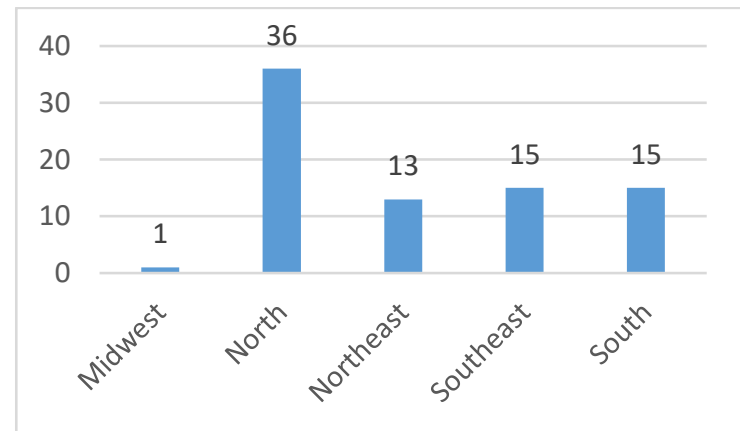

(a)

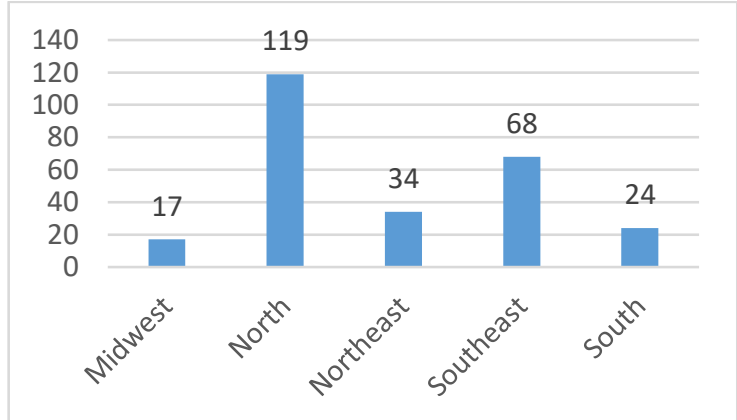

(b)

Source: Prepared by the authors

In Graph 1 (a), the result of the 2012 call is presented, grouped by region, where 80 municipalities were selected. In this chart, it is possible to verify that the 3 
regions with the highest number of municipalities selected were, in this order, the Northeast regions with 36 municipalities, South and Southeast with 15 municipalities both. Graph 1 (b) presents, by region, the result of the call of 2013, when 262 municipalities were selected. In this graph it can be verified that the 3 regions with the highest number of municipalities selected were the Northeast regions with 119 municipalities, Southeast with 68 municipalities and North with 34 municipalities.

In Graph 2 the quantity of selected municipalities in both calls, grouped by State.

Graph 2 - Municipalities selected by the MC in (a) 2012 and (b) 2013 grouped by State

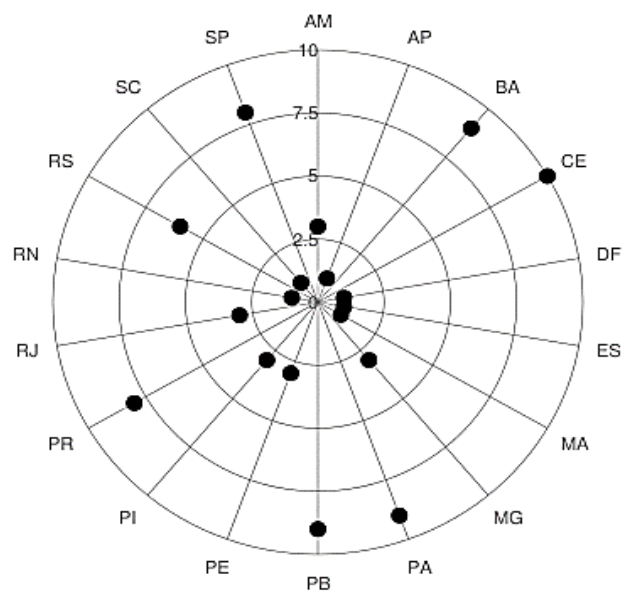

(a)

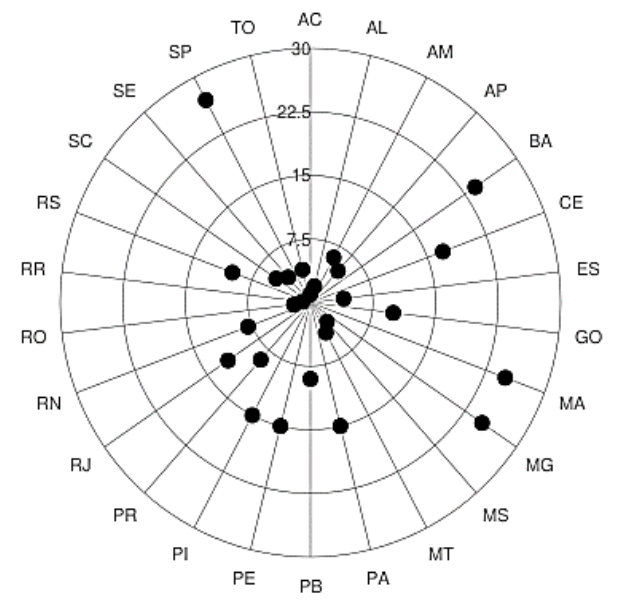

(b)

Source: Prepared by the authors

As we can see in Graph 2 (a), the 3 states with the highest number of municipalities selected in the first call were the states of Ceará (CE) with 10 municipalities, Pará (PA) and Paraíba (PB) with 9 municipalities. Figure 3 (b) shows that the 3 states with the highest number of municipalities selected in the second call were São Paulo (SP) with 27 municipalities, Maranhão (MA) and the state of Minas Gerais (MG) with 25 municipalities in both. In a meeting held by the MC in October 2013, with the selected municipalities, it was announced that only $3 \%$ were in the situation of Digital City implemented and $43 \%$ were still in the initial phase.

In the last report made available by the $M C$ at the electronic address "http://dados.gov.br/dataset/cidades-digitais", the number of municipalities considered 
for implementation of the project, such as "List of Cities Served", was 338. In this report they show, besides the municipalities involved, it is also presented data related to the planned and realized investment of each project (Graph 3).

Graph 3 - Comparative analysis between the values predicted and realized by the States (UFs)

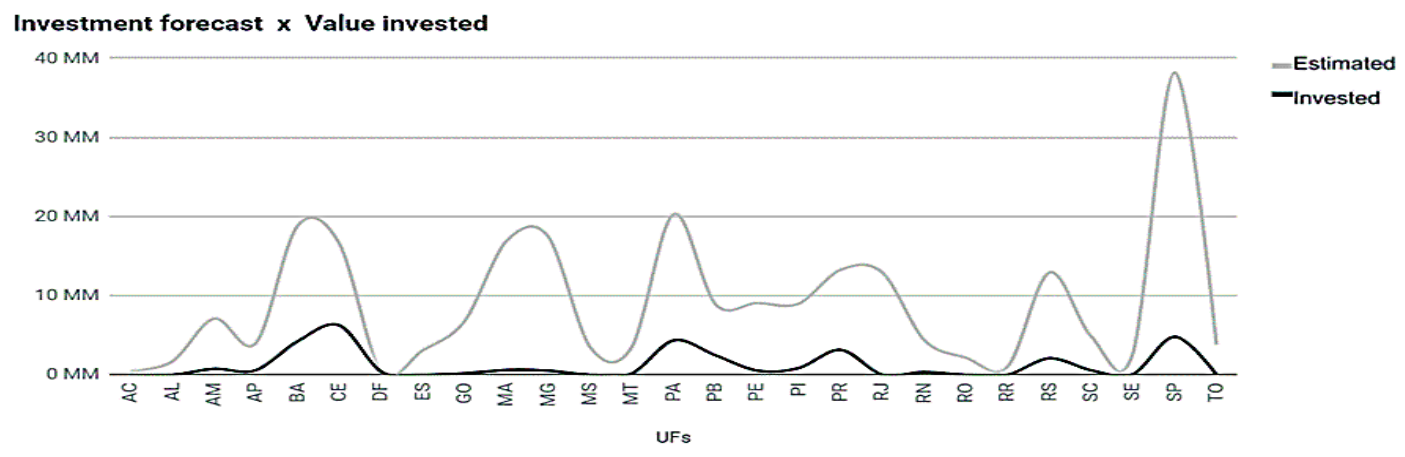

Source: Prepared by the authors

In Graph 3 we can see by the clearest line the projection of the predicted values, totalized by each Brazilian state. In the same graph, for comparison, it can be seen by the dark line the values effectively invested totalized by the states, and that can be explained by the fact that the vast majority of the projects are still in the initial phase and only a few are completed (Graph 4).

Graph 4 - Comparative analysis of the status of the projects

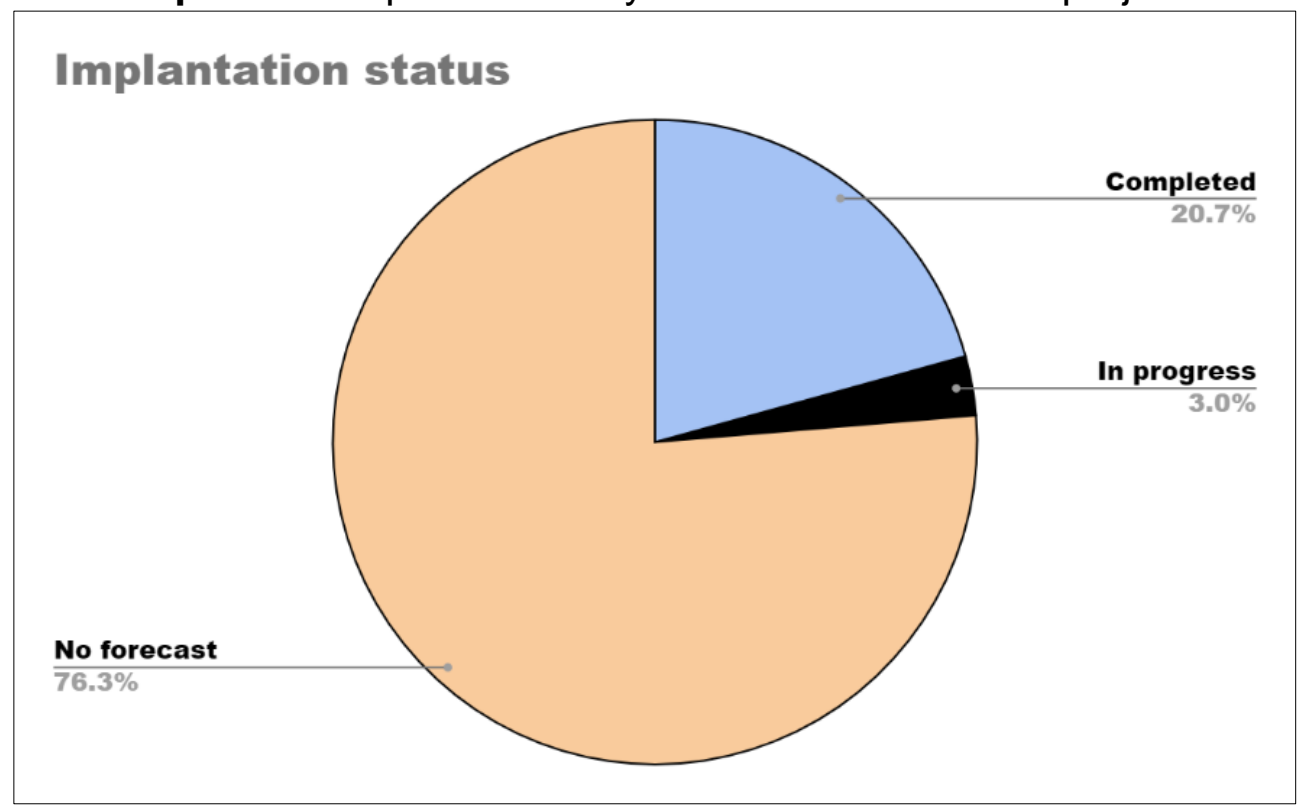

Source: Prepared by the authors 
In Graph 4 we observed that $76.3 \%$ of the projects have the status "No Forecast" which means that they are projects in the initial phase. Only 3\% started implantation and $20.7 \%$ were completed, that is 71 Digital Cities implanted (Table 3 ).

Table 3 - Total of Digital Cities implemented by State

\begin{tabular}{|r|rrr} 
STATE & Completed & \$ Expected & \multicolumn{1}{l}{ Invested } \\
CE & 11 & $6,220,732.07$ & $5,580,429.83$ \\
SP & 9 & $5,941,766.77$ & $4,586,500.11$ \\
PA & 9 & $6,445,406.89$ & $4,271,443.60$ \\
BA & 9 & $5,077,438.95$ & $4,247,075.04$ \\
PR & 7 & $4,263,895.07$ & $3,080,852.72$ \\
PB & 6 & $2,805,331.90$ & $2,474,393.50$ \\
RS & 4 & $2,290,903.51$ & $2,100,248.00$ \\
PI & 3 & $1,422,567.35$ & $382,085.00$ \\
AM & 3 & $2,343,733.77$ & $763,009.30$ \\
MG & 2 & $576,269.76$ & $529,344.45$ \\
SC & 1 & $597,782.80$ & $568,129.52$ \\
RN & 1 & $411,047.68$ & $139,501.10$ \\
RJ & 1 & $352,575.00$ & \\
PE & 1 & $485,264.10$ & $410,386.30$ \\
MA & 1 & $538,580.75$ & $432,278.00$ \\
DF & 1 & $421,957.11$ & $397,718.72$ \\
AP & 1 & $590,073.15$ & $495,899.00$ \\
GRAND TOTAL & $\mathbf{7 0}$ & $\mathbf{4 0 , 7 8 5 , 3 2 6 . 6 3}$ & $\mathbf{3 0 , 4 5 9 , 2 9 4 . 1 9}$
\end{tabular}

Source: Prepared by the authors

Table 3 shows that among the five states with the greatest number of Digital Cities, Ceará state occupies the first place followed by São Paulo, Pará, Bahia and Paraná. In this same table we can see that the total number of Digital Cities implemented to date is 70 projects, with a total investment of $R \$ 30.459,294.19$ which gives us an average value of $R \$ 435,132.77$ per Digital City completed.

\subsection{NÃO-ME-TOQUE TOWN (IN RIO GRANDE DO SUL STATE, RS)}

The municipality of Não-Me-Toque, a town in the state of Rio Grande do Sul, had its Digital City project approved in the first call of 2012. The project has already gone through at least 15 phases, as shown in Table 3 (NAO-ME-TOQUE, 2016; COSTA, 2016). According to the latest MC report, the project has the status of "Completed", with a population of 16,997 inhabitants. The initial project was estimated 
at $R \$ 566,980.26$ and it was invested up to its completion $R \$ 530,358.64$ with 18 points served.

Table 3 - Phases of Implantation of the Digital City Project in Não-Me-Toque / RS

\begin{tabular}{|c|c|}
\hline Date & Phase \\
\hline Mar / 2012 & $\begin{array}{l}\text { Ministry of Communications launches Call for Public Call on } 01 / 2012 \text {, for } \\
\text { Evaluation and Selection of Municipalities for centralized execution of the Digital } \\
\text { Cities Project }\end{array}$ \\
\hline May / 2012 & $\begin{array}{l}\text { Presented Proposal / Project of the Digital City of the Municipality of Não-Me- } \\
\text { Toque at the Ministry of Communications, according to Public Notice no 01/2012 }\end{array}$ \\
\hline Jul / 2012 & $\begin{array}{l}\text { Disclosure of the Municipalities contemplated with the Digital Cities Project, } \\
\text { being } 06 \text { in the RS (Não-Me-Toque, Candelária, Jari, Nova Bassano, Santo } \\
\text { Ângelo, São Miguel das Missões) }\end{array}$ \\
\hline Jan / 2013 & $\begin{array}{l}\text { Disclosure by the Ministry of Communications of the Integrating Companies } \\
\text { responsible for the Implementation of Infrastructure - Petcom Peltier Trade and } \\
\text { Industry }\end{array}$ \\
\hline Jan / 2013 & $\begin{array}{l}\text { Working Meeting in the Ministry of Communications, with the prefectures } \\
\text { contemplated and integrating companies. Signature of the Term of Technical } \\
\text { Cooperation between the Ministry of Communications and the Municipality }\end{array}$ \\
\hline Feb / 2013 & $\begin{array}{l}\text { Technical Training for the Implementation of the Digital Cities Project of the } \\
\text { Servers Marcio Martins Marques and Katiusca de Oliveira }\end{array}$ \\
\hline Jun / 2013 & $\begin{array}{l}\text { Signed Contract with the Concessionaire RGE, for Post Sharing, aiming at the } \\
\text { installation of the infrastructure (optical fiber) }\end{array}$ \\
\hline Feb / 2014 & Post Sharing Project approved by the RGE Concessionaire \\
\hline May 2014 & Obtaining a License for Station Operation at ANATEL \\
\hline Aug 2014 & $\begin{array}{l}\text { Integrator Company Petcom Peltier, started the Infrastructure deployment } \\
\text { process with fiber optic ring installation and physical structure adaptation of the } \\
\text { points (PEAS, SGI, PAG and PAP) }\end{array}$ \\
\hline Aug 2014 & $\begin{array}{l}\text { Training of the servers Marcio Martins Marques and Gian Lucas Heller, in the } \\
\text { course of "Training in Strategic Management of IT in the Municipal } \\
\text { Administration" a total of } 40 \text { hours, in Porto Alegre -RS, conducted at Escola } \\
\text { Superior de Redes }\end{array}$ \\
\hline Feb / 2015 & $\begin{array}{l}\text { Technicians from the Ministry of Communications carried out an inspection of } \\
\text { the }\end{array}$ \\
\hline Feb / 2015 & PetCom company Training \\
\hline Mar / 2015 & mpany and contra \\
\hline May / 2015 & fficially launched of the Digital City Program of Não-Me-Toque town \\
\hline
\end{tabular}

Source: Prepared by the authors

The final technical specification of the infrastructure of the Digital City of NãoMe-Toque presented was: Fiber Optic ring with extension of $11 \mathrm{~km} ; 01 \mathrm{SGI}$ Infrastructure Management Solution; 01 PEAS - Link Point and Social Access (Central); 03 PAPs - Public Access Point; 14 PAGs - Government Access Point; and contracted broadband speed of 18 megabits Full from the company TryWay Coprel ; a total of $2 \mathrm{~km}$ and 200 meters of optical fiber and 60 meters of shielded cable. 
Access points were made available in various locations around the city, Figure

4.

Figure 4 - Access Points

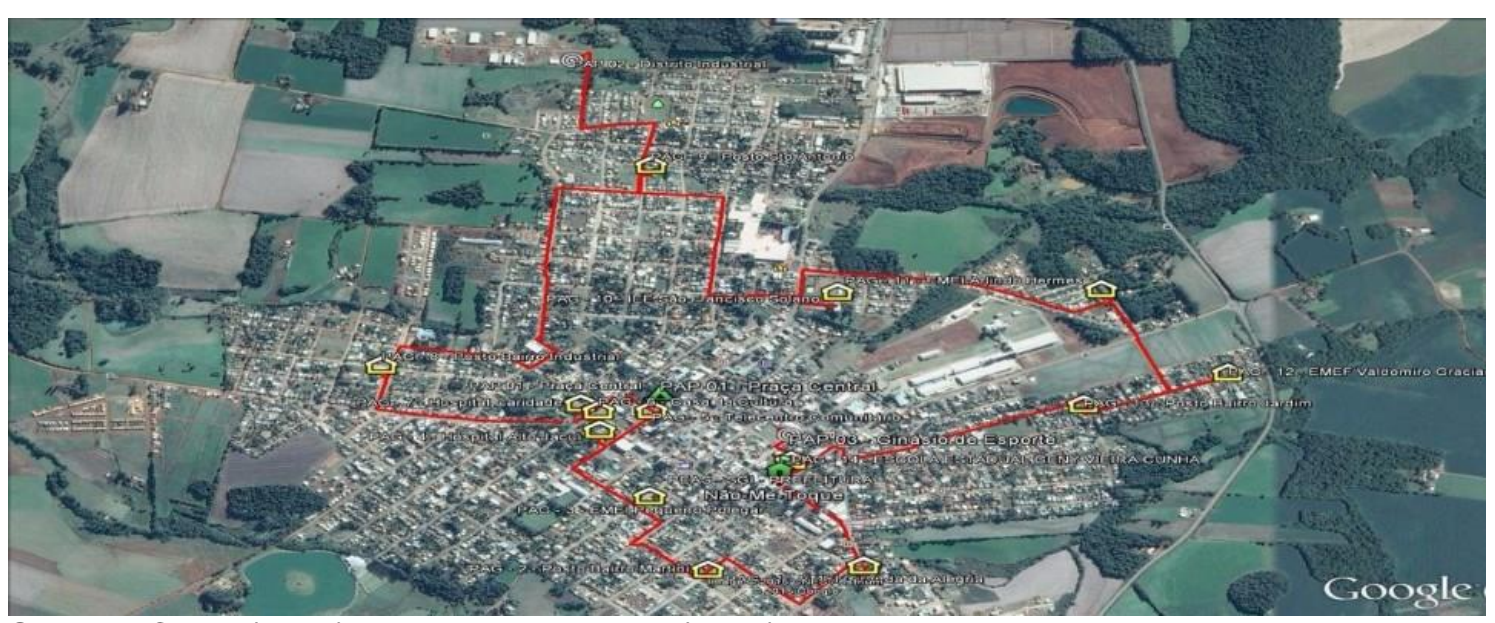

Source: Costa (2016) and Não-Me-Toque (2016)

As shown in Figure 4, the access points were public agencies of the city such as telecenters and culture offices of the city; health posts; elementary and middle schools; philanthropic hospitals; and public access points in the town square, sports gymnasium and industrial district. For the improvement of municipal management, the following software were installed: E-SUS, for interconnection of all health posts with the digital city network, we were able to implement the federal government's electronic health record program; Spark, which is an internal communicator for file exchange and instant messaging; and remote access service on the machines.

\section{CONCLUSION}

Through this study, it was possible to identify and describe the different approaches and concepts related to Digital Cities. It is observed that all of them are related in some way to the use of ICTs. The projects of Digital Cities at the initiative of the public authority, in the form of public policies, seek to make effective the use of ICTs to make public management more efficient and offer quality services to citizens, as well as their insertion in the information society. 
In Brazil, the Digital Cities project created and managed by the Ministry of Communications aims to reduce the distortions between the Brazilian municipalities, regarding the access and use of ICTs. They also seek to insert some minorities in the information universe through the use of ICTs. It is an innovative project, in the long term, and with great challenges, but it is already possible to observe some results, still small in view of the number of municipalities served.

This study, however, identified that in a universe of 5,565 municipalities, where around 5,037 according to Brazilian IGBE (2000) have up to 50,000 inhabitants, and are therefore able to present Digital Cities projects, only 338 did so. Out of this universe, only 70 municipalities had projects of Digital City implanted, which represents a very small number in relation to the amount of "potential" existing cities. This means that the project needs to move forward in order to identify the difficulty these municipalities face in presenting projects. It also demonstrates the need for improvements in the program to give more agility to the projects that are approved, so that they can be implemented and the municipality with access to the technologies provided by the project in order to offer more benefits to its citizens.

\section{REFERENCES}

ANGELIN, SFN; DE MEZA, M.L.F.G. The challenges of public administration for the insertion of cities in the information society. PRACS: Electronic Journal of Humanities of the Course of Social Sciences of UNIFAP, v. 8, n. 2, p. 209-228, 2016.

BRAZIL. Ministry of Communications. Secretariat of Digital Inclusion. Digital Cities; building an ecosystem of cooperation and innovation: Reference Document of the Digital Cities Project, 2014.

CASTELLS, Manuel; MAJER, Roneide Venancio. Gerhardt. Klauss Brandini. A sociedade em rede, v. 4, 2002.

COSTA, G. Não-Me-Toque is a reference in a digital city in Alto Jacuí (RS). Site Digital City Network, 2016. Available at: http://redecidadedigital.com.br/noticias.php?id=1296\&data=N\%C3\%A3o-MeToque\%20\%C3\%A9\%20refer\%C3\%A3\%A\%20 Access on (06/06/2016).

DE CASTRO, JG Digital Cities: an analysis of the implementation of the infrastructure in its pilot project. 2015. 
DEMOGRAPHIC, Census. Brazilian Institute of Geography and Statistics (IBGE). 2010.

GIL, AC People Management: focus on professional roles. São Paulo: Atlas, 2001.

GUERREIRO, EP Digital city: social infoinclusão and technology in network. Senac, 2006.

IBGE. Municipal Social Indicators - 2000. Site Brazilian Institute of Geography and Statistics, 2010.

http://www.ibge.gov.br/home/estatistica/populacao/indicadores sociais municipais/ta bela1a.shtm Access on 08/08/2016

ISHIDA, T.; ISBISTER, K. (Ed.). Digital cities: technologies, experiences, and future perspectives. Springer Science \& Business Media, 2000.

LEITE, J. From the real city to the digital city: the virtualization of urban structures in the construction of public cyberspace. Reason and word, v. 49, p. 39-50, 2006.

LEMOS, A. What is a digital city? Guide to Digital Cities, 2006. Available at $<$ http://www.guiadascidadesdigitais.com.br/site/pagina/o-que-cidade-

digital $>$. Accessed on <06/01/2016>

City- cyborg : the city in cyberculture . Galaxy, v. 4, n. 8, 2007.

LÉVY, Pierre. Cyberculture. U of Minnesota Press, 2001.

LIMA, Valéria Ferreira Santos de Almada. Reform of the state and social control: limits and possibilities of decentralization and the "third sector". Revista Política Públicas, v. 6, n. 2, p. 127-147, 2015.

Ministry of Communications. Digital Cities, 2015. Available at <http://www.comunicacoes.gov.br/cidades-digitais> Access on (06/01/2016).

Não Me Toque City Hall. Site of the City Hall, 2016. Available at $<$ http://naometoquers.com.br>. Access on 06/30/2016.

WELLMAN, B. et al. Does the Internet increase, decrease, or supplement social capital? Social networks, participation, and community commitment. American behavioral scientist, v. 45, n. 3 , p. 436-455, 2001.

REZENDE, DA. Planning of municipal information and strategies for digital city: a guide for projects in prefectures and public organizations. São Paulo: Atlas, 2012.

. Lecture Notes of the Strategic Digital City Discipline. Curitiba: Pontifical Catholic University of Paraná, 08/08/2016. 
REZENDE, Denis Alcides. Strategic Planning and Management of a Brazilian City: Many Words and Few Accomplishments. IJAME, 2018.

TEIXEIRA, Alex V.; DUARTE, MC Freitas; LAURINDO, Alisson M. Engineering Information: conceptual elements related information management and information systems. In: Edulearn14 Proceedings. IATED, 2014. p. 6909-6915.

TOFFLER, A. The third wave: the death of industrialism and the birth of a new civilization. Rio de Janeiro: Record, 1980.

VERGARA, SC Management of people. 4. Ed. São Paulo - Atlas, 2005.

YIN, RK Case Study Research. Design and Methods. Sage Publications Inc., USA, 1989. 